\title{
Dendrochronological study of Cedrus deodar Grown at Kumrat valley Dir Upper KPK, Pakistan: Evaluation of Tree Age and Increment Based on Increment Core
}

\section{(Studi Dendrokronologis pada Cedrus deodar yang Tumbuh di Lembah Kumrat Dir Upper KPK, Pakistan: Evaluasi Umur Pohon dan Riap Pertumbuhan Berdasarkan Increment Core)}

\author{
Sajad' ${ }^{1}$, Jawad $^{2}$, Ikram ul Haq ${ }^{3}$ \\ (Received May 2020/Accepted February 2021)
}

\begin{abstract}
The present research was conducted for tree-rings study in a mixed stand of Himalayan Species Credur deodar in Kumrat valley Dir Upper KPK, Pakistan. Tree-rings analysis was related to the counting of tree ring. Random sampling method was used, and 70 sample trees were selected, tree heights and diameters were measured, and increment cores were collected from each sample-tree diameter at the height at breast point to be analyzed and studied in the laboratory. The objectives of the study were to determine the exact age of tree and to evaluate total and mean annual increment in the basal area and tree volume based on the increment cores. Regression models revealed the impacts of tree age on the basal area and tree-volume increment. Results showed the minimum basalarea increment was $0.0028 \mathrm{~m}^{2}$ at the age of 10 years, the maximum basal-area increment was $2.658 \mathrm{~m}^{2}$ at the age of 60 years, with mean was $0.95 \pm 0.677 \mathrm{~m}^{2}$ at the age of 36 years and $R^{2}$ was 0.9593 . The maximum tree-volume increment was $1.42 \mathrm{~m}^{3}$ at the age of 60 years, the minimum tree-volume increment was $0.010 \mathrm{~m}^{3}$ at the age of 10 years, with mean was $1.35 \pm 0.96 \mathrm{~m}^{3}$ at the age of 36 years and $R^{2}$ was 0.9167 . The minimum mean annual-basal area increment was $0.0027 \mathrm{~m}^{2}$, the maximum mean annual-basal area increment was $0.048 \mathrm{~m}^{2}$, and the average increment was $0.022 \pm 0.010 \mathrm{~m}^{2}$. The maximum mean-annual increment in tree volume was $0.068 \mathrm{~m}^{3}$ at the age of 60 years, the minimum mean-annual increment was $0.0039 \mathrm{~m}^{3}$ at the age of 10 years, with mean was $0.032 \pm 0.014 \mathrm{~m}^{3}$ at the age of 36 years and $R^{2}$ was 0.8903 . Results showed a strong positive relationship of tree age with area and volume increment.
\end{abstract}

Keywords: Basal area, increment, tree age, volume

\section{ABSTRAK}

Penelitian ini dilakukan untuk mempelajari riap pertumbuhan (pertambahan massa kayu) pada pohon Credrus deodar dari tegakan campuran di lembah Kumrat Dir Upper KPK, Pakistan. Analisis riap tumbuh berkaitan dengan penghitungan lingkaran tumbuh yang ada. Penelitian ini menggunakan 70 pohon sampel yang dipilih secara acak. Dari setiap pohon sampel, tinggi dan diameter batang diukur, lalu increment core pada ketinggian setinggi dada dikumpulkan untuk dianalisis di laboratorium. Tujuan penelitian adalah menentukan umur pohon sebenarnya dan mengevaluasi riap total tahunan dan riap rata-rata tahunan pada basal area dan volume pohon berdasarkan increment core. Model regresi digunakan untuk menganalisis pengaruh umur pohon pada riap pertumbuhan basal area dan riap volume pohon. Hasilnya menunjukkan pertambahan basal area minimum adalah $0,0028 \mathrm{~m}^{2}$ pada umur 10 tahun dan maksimum adalah $2,658 \mathrm{~m}^{2}$ yang dicapai pada umur 60 tahun, dengan rata-rata $0,95 \pm 0,677 \mathrm{~m}^{2}$ pada umur 36 tahun dan $R^{2}$ sebesar 0,9593 . Pertambahan volume pohon maksimum adalah $1,42 \mathrm{~m}^{3}$ pada usia 60 tahun, minimum adalah $0,010 \mathrm{~m}^{3}$ pada umur 10 tahun, dengan rata-rata $1,35 \pm 0,96 \mathrm{~m}^{3}$ pada umur 36 tahun dan $R^{2}$ sebesar 0,9167 . Ratarata riap tahunan minimum pada basal area adalah $0,0027 \mathrm{~m}^{2}$, maksimum adalah $0,048 \mathrm{~m}^{2}$, dengan rata-rata $0,022 \pm$ $0,010 \mathrm{~m}^{2}$. Rata-rata riap tahunan volume pohon maksimum adalah $0,068 \mathrm{~m}^{3}$ pada umur 60 tahun, riap tahunan volume pohon minimum adalah $0,0039 \mathrm{~m}^{3}$ pada umur 10 tahun, dengan rata-rata $0,032 \pm 0,014 \mathrm{~m}^{3}$ pada umur 36 tahun dan $R^{2}$ sebesar 0,8903 . Hasil penelitian menunjukkan adanya korelasi positif yang kuat antara umur pohon dengan riap basal area dan riap volume.

Kata kunci: Basal area, increment, umur pohon, volume

${ }^{1}$ Department Forest Management, Faculty of Forestry, Universitas Gadjah Mada, Jl. Agro No. 1 Bulaksumur, Sleman 55281

2 Department of Forest Products Technology, Faculty of Foresty, Universitas Gadjah Mada, JI. Agro No. 1 Bulaksumur, Sleman 55281

${ }^{3}$ Wildlife and Forestry Management, Faculty of Forestry and Wildlife, University of Haripur KPK, Pakistan

* Corresponden Author: Email: sajad@mail.ugm.ac.id

\section{INTRODUCTION}

The word "Dendrochronology" is derived from three Greeks words "Dendro" means "tree", "Cronos" means "time", and "logos" mean "studies" or "discussion". Dendrochronology meaning of "tree-ring analysis" is 
the science that is used for tree rings to calculate the exact age of a tree species (Heuret et al. 2016). Trees develop a ring annually which varies in thickness and density due to several reasons. In all conifers, tree rings are visible and wider but in broad-leaves trees, tree rings are close, dense, and are not visible due to its compactness (Fichtler 2017). The absence of clearly identifiable annual growth rings in broad-leaved tree species made it difficult for cutting rotation and forest management in comparison to clear and visible growth rings of conifers tree species (Zhao et al. 2019). The development of annual rings in trees is highly affected by ecological factors i.e., precipitation, temperature, latitude, altitude, and even by the species type (Ols et al. 2018). The study of tree-ring analysis is an important and effective tool that is widely applied in ecological studies for determining the exact ages of tree species (Locosselli et al. 2019). Dendrochronology (the treering studies) recently emerged as a field and is rapidly growing science, was started in 1986 in Pakistan, while systematic studies were started in 2005 . It has a diverse relevance with different fields, i.e., ecology, forestry, earthquake, glacial hydrology, climatology, archeology, population dynamics, and many more other disciplines (lqbal et al. 2017a). Current dendrochronological techniques are applied to attain estimation studies for age and growth rate of pine trees. Some published data are available for tree species in Pakistan (Arsalan et al. 2020; Bokhari et al. 2013; lqbal et al. 2017b). Modern dendrochronological tools and techniques enable to calculate age and growth rate in various sites and locations like Himalayan ranges of Pakistan in terms of moist and dry temperature. Modern and advanced dendrochronological studies indicated the suitability of such species as far as age and growth rate relationship is concerned(Arsalan et al. (Arsalan et al. 2020). The research investigated 39 different sites of Swat, Dir, Chitral, Mansehra, Abbottabad, Northern areas, and Azad Kashmir to estimate age and growth rates of six gymnosperms tree species (ljaz et al. 2018). The same technique was used to investigate C.deodara and Pinus gerardiana species from Chitral District to estimate age and growth rates of tree species from District Dir (Adam Khan et al. 2018) and the study presented very unique data from Shangla District of Khyber of Pakhtunkhwa in which Himalayan and Hindukush regions have been investigated as samples of moist temperatures to attain age and growth rate of the dominant conifers tree species (Arsalan et al. 2020; lqbal et al.2020). A brief introduction to dendrochronology, its applications, and scope in the Himalayan region of Pakistan are presented by (Bhandari, 2019) . Modern tree-ring chronologies of Abies pindrow Royle from the Himalayan region of Pakistan was also studied. A dendrochronological approach to estimate age and growth pattern of various species and dendrochronological potential of a few tree species from the Himalayan region of Pakistan was elaborated by Hussain et al. (2018) and lqbal et al. (2020).
Problems encountered with tree-age estimation to investigate the dendroclimatic potential and age/growth rates of many gymnosperm species were also reported (Sarangezaj, 2017; Xing et al. 2017). Tree-ring chronologies and growth-climate results from the Upper Indus Basin of Karakorum Range of Pakistan are reported. Twenty-eight chronologies of Conifers from Northern areas of Pakistan are also reported. The recent study was conducted in a mixed forest of the Cedrus deodar forest in Kumrat valley Dir Upper, Khyber Pakhtunkhwa Pakistan. In Pakistan, the Cedrus deodar forest is distributed in Dir, Chitral, Gilgit, and Swat. There was no proper scientific study has been conducted on dendrochronological and increment based on Cedrus deodar forest stand in Pakistan. The current research study provides detailed information and field protocol regarding tree-ring analysis and increments based on increment core in the Cedrus deodar forest. A recent research study was carried out in $C$. deodarforest in Kumrat valley of Hindukush range of Khyber Pakhtunkhwa Pakistan. The objective of the present study was to estimate the exact age of natural forest of Cedrus deodar and to evaluate the total growth (increment) and mean annual increment of Cedrus deodar forest in Kumrat valley, Hindukush range of Khyber Pakhtunkhwa, Pakistan.

\section{MATERIAL AND METHODS}

\section{Study Site}

The present study was conducted by using a mixed stand of Cedrus deodar in Kumrat valley Dir Upper, KPK, Pakistan to study the tree rings. In the study area, the stand was the mixed combination of Cedrus deodar and Pinus willichania. However, Cedrus deodar was the dominant species in the area. The valley is located at $35.15^{\circ} \mathrm{N}$ latitude and $71.22^{\circ}$ toward east longitude at an elevation range of 1420 meters above the sea level. The study area is in the Hindukush range of Pakistan. The soil of the study site is shallow and acidic, and the major rocks of the valley include diorite, schist, and granite. The mean annual precipitation ranges from $750 \mathrm{~mm}$ to $1000 \mathrm{~mm}$. The annual temperature ranges from 0.7 to $30^{\circ} \mathrm{C}$. The value of soil $\mathrm{PH}$ (power of hydrogen) is in the range of 6.5 to 7.5.

\section{Research Design}

This study was conducted to evaluate the exact age, basal area, and tree volume of Cedrus deodar. Inventory method was conducted into the mixed forest of Cedrus deodar, and the sample trees were randomly selected in the Kumrat valley of Dir Upper, KPK, Pakistan. Tree height $(\mathrm{m})$, diameter $(\mathrm{cm})$, and crown cover $\left(\mathrm{m}^{2}\right)$ were measured in each sample tree and were recorded being as a sampled tree. For documentation of tree age, tree-ring cores (sample core) were collected from each sampled tree by using Swedish Pressler borer and kept in specified labelled covers. Tree diameter, height, and crown cover were 
recovered from each sample tree on the cover of sample cores. The cores were brought to the laboratory for further analysis. Sample cores were polished to make the annual rings clearer and more visible. The tree age of each sample was calculated by carefully counting annual rings from sample cores. The height of the tree was measured by Stafford, Abney-level, and directly by climbing. The height of the staff rod was 7.31 $\mathrm{m}$ so the trees having a height $\leq 7.31 \mathrm{~m}$ or $7.31 \mathrm{~m}$ were measured by staff rod. Tree diameter was measured at two points i.e., diameter at breast height (DBH) for the calculation of cylindrical volume and diameter at midpoint (DMP) for the calculation of actual volume. The diameter of trees at $\mathrm{DBH}$ was measured by using a caliper.

\section{Estimation and Measurement of Basal-Area Increment}

Basal rea is the cross-sectional area of a tree stem which was calculated from $\mathrm{DBH}$ and the following formula was used to find out the total basal-area increment or growth of each sample tree (Alamgir Khan et al. 2015; Sajad et al. 2020)

$$
B A\left(m^{2}\right)=1 / 4 \pi D^{2}
$$

Description:

$$
\begin{array}{ll}
\mathrm{BA} & =\text { Basal area } \\
\mathrm{D} & =\text { Diameter and } \pi \text { is constant }
\end{array}
$$

While the mean annual increment in the basal area for each sample tree was also calculated by using the following formula:

$$
\text { MAI basal area }\left(\mathrm{m}^{2}\right)=\text { TTBA }\left(\mathrm{m}^{2}\right) / \text { TTA (years) }
$$

Description:

MAl basal area $=$ The mean annual increment of basal area

TTBA $=$ The total tree basal area, and TTA is the total tree age

\section{Measurement and Estimation of Tree-Volume Increment}

Tree volume was estimated for each sample tree by using the following formula.

$$
V\left(m^{3}\right)=1 / 4 \pi D^{2} \times H(m) \times F F
$$

Description:

$\begin{array}{ll}\mathrm{V} & =\text { Volume of stem }\left(\mathrm{m}^{3} \mathrm{ha}^{-1}\right) \\ \mathrm{H} & =\text { Height of tree in meter } \\ \mathrm{BA} & =\text { Cross-sectional basal area at } \mathrm{DBH} \text { point } \\ \pi & =\text { Constant } \\ \mathrm{FF} & =\text { Form factor }\end{array}$

For the present study, the form factor for each tree in the respective diameter class was calculated (Alamgir Khan et al. 2015; Sajad et al. 2020). While the mean annual increment in tree volume was also calculated for each sample tree by using the following formula:

$$
\text { MAI V }\left(m^{3}\right)=\operatorname{TTV}\left(m^{3}\right) / \text { TTA (years) }
$$

Description:

$\mathrm{MAI} \mathrm{V}=$ Annual increment of tree volume

TTV = Total tree volume

TTA $=$ Total tree age

\section{Statistical Analysis}

For data analysis, the authors used the following software: MS EXCEL, PAST, and Sigma Plot. The primary data were arranged in Excel sheets to calculate tree volume, basal area, and mean annual increment in tree volume and basal area, while univariate statistics were carried out in the PAST. The figures and graphs were developed in Sigma Plot version 10.1 as well as the regression models. A simple linear regression model was used to find out the impact of tree age on tree basal area, volume, and mean annual increment in tree basal area and volume.

\section{RESULTS AND DISCUSSION}

\section{Tree Age Relation with Increment in Basal-Area Increment}

The parameters studied consisted of tree age, basal area, and tree volume. The results showed that the minimum age of the sample tree was 10 years with the increment in total basal area was $0.028 \mathrm{~m}^{2}$, while the maximum age of the sample was 55 years and the increment in total basal area was $2.65 \mathrm{~m}^{2}$. The second maximum increment in total basal area was $2.62 \mathrm{~m}^{2}$ estimated at the age of 60 years while the second minimum increment in total basal area was $0.159 \mathrm{~m}^{2}$ at age of 11 years. The average age of the sample tree was 36.68 years with the increment in total basal area was $0.95 \pm 0.67 \mathrm{~m}^{2}$. Table 1 shows that the age of the sample tree was increased with the increase in total basal area which shows a strong positive correlation of tree age with the increment in total basal area. The coefficient of variance and standard deviation are presented in Table 2 for tree age with increment in total basal area of sample trees. The sum of the total basal area increment in all sample trees was $66.616 \mathrm{~m}^{2}$ which is presented in Table 2 .

The minimum mean of annual total basal-area increment was $0.0027 \mathrm{~m}^{2}$ estimated at the age of 10 years while the second minimum mean annual total basal-area increment was calculated at the age of 11 years old (Hussain et al. 2018). The maximum mean annual total basal-area increment was calculated at the age of 55 years old sample tree, while the second maximum mean annual total basal-area increment was $0.043 \mathrm{~m}^{2}$ at the age of 60 years old tree which are presented in Table 1. The tree age shows relation with mean annual increment in the total basal area which are presented in Table 1 . The average means annual increment in total basal area was $0.022 \pm 0.010$ $\mathrm{m}^{2}$ at the age of 36 years, while the sum of mean annual basal-area increment in all sample trees was 
Table 1 Tree age relation with total and mean annual basal area/tree

\begin{tabular}{ccccccccc}
\hline $\begin{array}{c}\text { Age } \\
\text { Years })\end{array}$ & BA $\left(\mathrm{m}^{2}\right)$ & $\begin{array}{c}\text { Mean Annual } \\
\text { BA }\left(\mathrm{m}^{2}\right)\end{array}$ & $\begin{array}{c}\text { Age } \\
\text { (Years })\end{array}$ & BA $\left(\mathrm{m}^{2}\right)$ & $\begin{array}{c}\text { Mean Annual } \\
\text { BA }\left(\mathrm{m}^{2}\right)\end{array}$ & $\begin{array}{c}\text { Age } \\
(\text { Years })\end{array}$ & $\begin{array}{c}\text { BA } \\
\left(\mathrm{m}^{2}\right)\end{array}$ & $\begin{array}{c}\text { Mean Annual } \\
\text { BA }\left(\mathrm{m}^{2}\right)\end{array}$ \\
\hline 10 & 0.0280 & 0.0030 & 35 & 0.6010 & 0.0170 & 45 & 1.0700 & 0.0240 \\
11 & 0.1590 & 0.0140 & 35 & 0.6430 & 0.0180 & 45 & 1.2220 & 0.0270 \\
12 & 0.1420 & 0.0120 & 36 & 0.6940 & 0.0190 & 45 & 1.2360 & 0.0270 \\
13 & 0.1000 & 0.0080 & 36 & 0.5410 & 0.0150 & 46 & 1.2270 & 0.0270 \\
15 & 0.1160 & 0.0080 & 36 & 0.6220 & 0.0170 & 46 & 1.2960 & 0.0280 \\
15 & 0.1260 & 0.0080 & 37 & 0.7500 & 0.0200 & 47 & 1.3570 & 0.0290 \\
15 & 0.1540 & 0.0100 & 37 & 0.7730 & 0.0210 & 47 & 1.3990 & 0.0300 \\
15 & 0.1500 & 0.0100 & 37 & 0.7200 & 0.0190 & 47 & 1.2460 & 0.0270 \\
16 & 0.1870 & 0.0120 & 37 & 0.5910 & 0.0160 & 47 & 1.2170 & 0.0260 \\
19 & 0.1980 & 0.0100 & 37 & 0.7850 & 0.0210 & 49 & 1.4040 & 0.0290 \\
20 & 0.2420 & 0.0120 & 37 & 0.8740 & 0.0240 & 49 & 1.5220 & 0.0310 \\
20 & 0.1770 & 0.0090 & 38 & 0.9370 & 0.0250 & 50 & 1.5390 & 0.0310 \\
20 & 0.3070 & 0.0150 & 39 & 0.9760 & 0.0250 & 50 & 1.5610 & 0.0310 \\
25 & 0.4500 & 0.0180 & 39 & 0.7730 & 0.0200 & 50 & 1.6330 & 0.0330 \\
28 & 0.5940 & 0.0210 & 40 & 0.9280 & 0.0230 & 51 & 1.7780 & 0.0350 \\
28 & 0.5440 & 0.0190 & 40 & 0.9630 & 0.0240 & 52 & 1.9910 & 0.0380 \\
29 & 0.1450 & 0.0050 & 42 & 1.0070 & 0.0240 & 53 & 2.1830 & 0.0410 \\
30 & 0.5810 & 0.0190 & 43 & 0.9760 & 0.0230 & 53 & 2.2290 & 0.0420 \\
30 & 0.6180 & 0.0210 & 43 & 1.0560 & 0.0250 & 53 & 2.4040 & 0.0450 \\
32 & 0.4470 & 0.0140 & 43 & 0.8650 & 0.0200 & 54 & 2.4320 & 0.0450 \\
32 & 0.6080 & 0.0190 & 43 & 1.0200 & 0.0237 & 55 & 2.5220 & 0.0459 \\
33 & 0.6360 & 0.0193 & 43 & 1.0840 & 0.0252 & 55 & 2.6580 & 0.0483 \\
33 & 0.3850 & 0.0117 & 44 & 1.1540 & 0.0262 & 60 & 2.6220 & 0.0437 \\
34 & 0.4420 & 0.0130 & & & & & & \\
\hline
\end{tabular}

Table 2 Descriptive statistics of tree age relation with total and mean annual basal area

\begin{tabular}{lcccccccc}
\hline \multicolumn{1}{c}{ Variable } & Unit & $\mathrm{N}$ & Min & Max & Mean & Sum & SD & CV $(\%)$ \\
\hline Age & Years & 70 & 10 & 60 & 36.87 & 2581 & 12.75 & 34.59 \\
Basal area (BA) & $\mathrm{m}^{2} /$ tree & 70 & 0.0280 & 2.658 & 0.95 & 66.617 & 0.677 & 71.15 \\
Mean annual BA & $\mathrm{m}^{2}$ tree & 70 & 0.0027 & 0.048 & 0.022 & 1.587 & 0.010 & 45.76 \\
\hline
\end{tabular}

$1.587 \mathrm{~m}^{2}$ which are presented in Table 2. The standard deviation and coefficient of variance of total and mean basal-area increment are presented in Table 2.

Figure 1 shows a strong positive correlation between tree age with increment in total basal area of sample trees. When the tree age was 10 years the total increment of basal area was $0.028 \mathrm{~m}^{2}$, but at 55-yearold it reached $2.658 \mathrm{~m}^{2}$ which showed a positive correlation, when age of the tree increased the increment in the basal area also increased and the value of $R^{2}$ was 0.9593 . $R^{2}$ showed a strong positive correlation among tree ages with the increment of total basal-area detail are presented in Figure 1.

Figure 2 shows tree age relation with total mean annual increment in the basal area. When the tree age was 10 years old the total mean annual-increment of basal area was $0.0027 \mathrm{~m}^{2}$ which showed a minimum mean annual basal-area increment while the maximum mean annual basal-area increment was $0.048 \mathrm{~m}^{2}$ at the age of 55 years and the second maximum mean annual-increment in basal area was $0.043 \mathrm{~m}^{2}$ at the age of 60 years old sample tree. When the age of the tree was increased with the increment in the mean annual basal area from 10 to 60 years, the result showed a strong positive correlation which is presented in Figure 2. The value of $R$ square was 0.8809 which shows a positive correlation between tree age with mean annual basal-area increment. The tree age was increased with the increase in mean annual basalarea increment. Regression model for the correlation between tree age with total basal-area increment is polynomial cubic equation while regression model for the correlation between tree age with the mean annual increment in basal area is polynomial quadratic. According to previous research and its results shows that Aboveground ecosystem basal area increased considerably during the first two decades after establishment and between the age of 30 and 65 . Belowground ecosystem basal area remained stable during the early decades and then started to increase with stand age due to an increase in total tree root biomass. Thus, the phase of stand maturing between the age of 30 and 60 may be considered most important for basal area due to an increase in both the above and belowground ecosystem basal area (Peichl \& Arain, 2006). While this research shows the tree age impact on basal area increment in the stand which define that when the tree age was increase with increase in basal area increment of the trees, current value resembles with the previous results in terms of volume, basal area, volume, biomass, and carbon stocks

\section{Tree Age Relation with Tree-Volume Increment}

The results showed that the minimum age of the sample tree was 10 years old with the total volume 


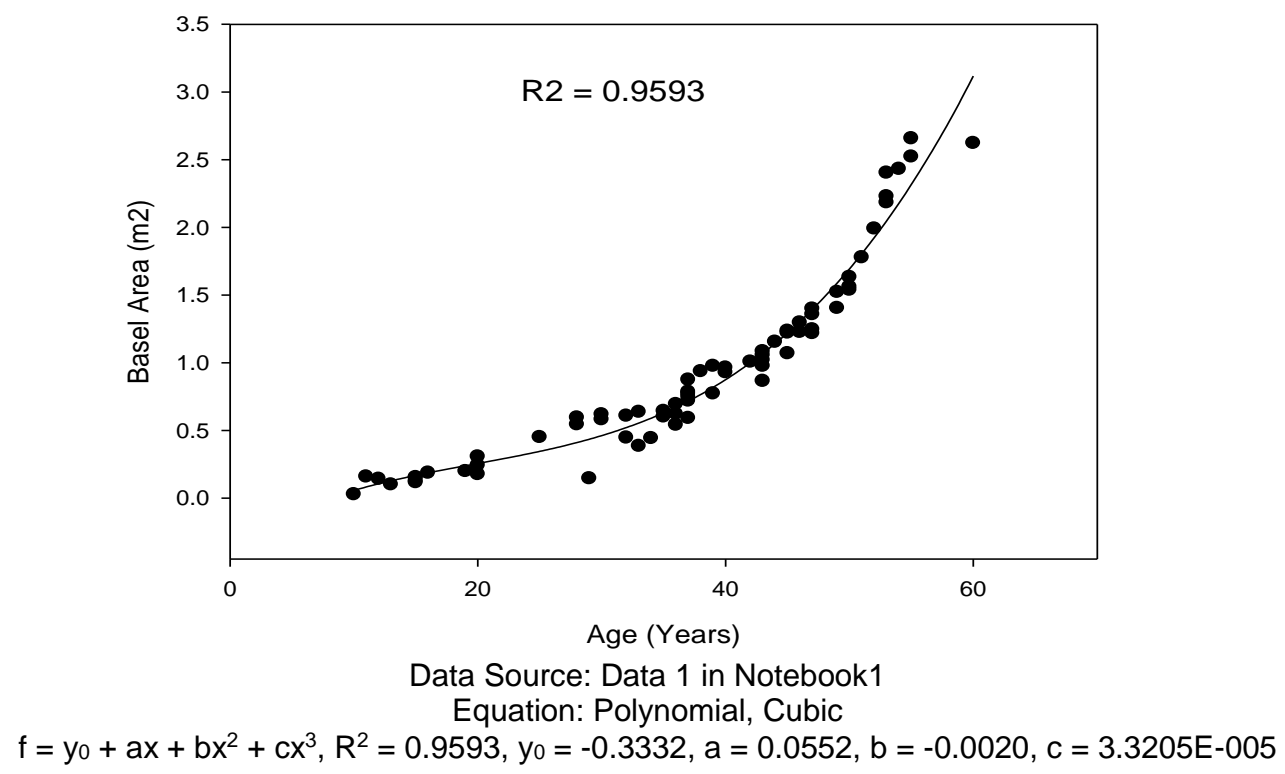

Figure 1 Tree age relation with total Basal area.

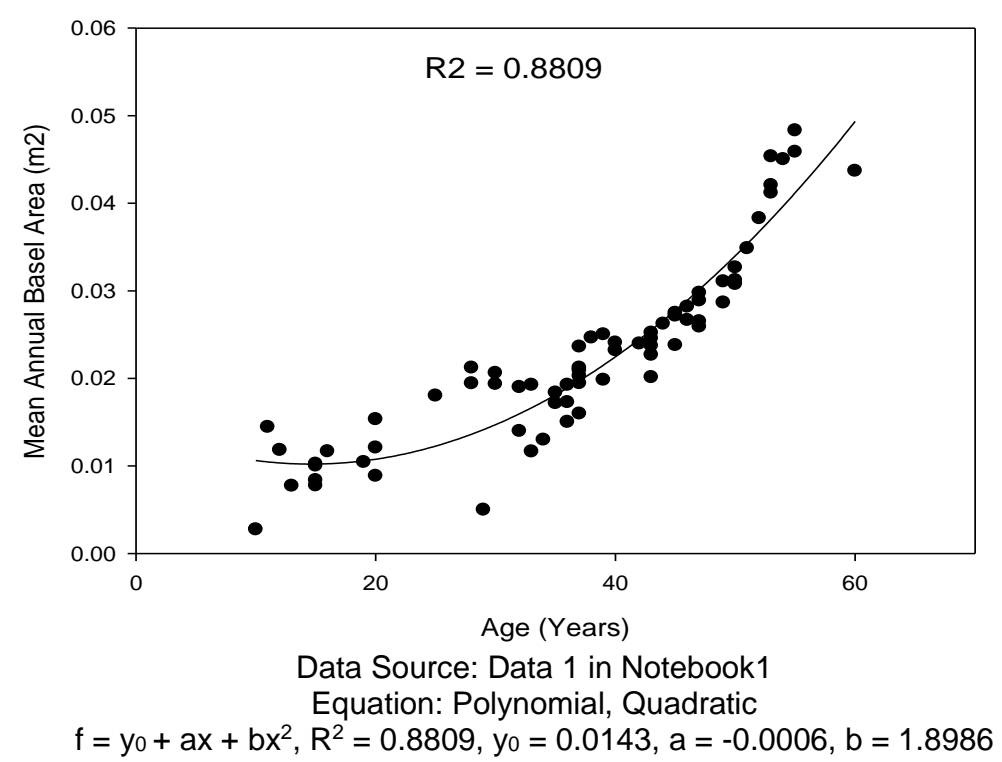

Figure 2 Tree age relation with mean annual Basal area.

increment was $0.010 \mathrm{~m}^{3}$, while at the age of 55 years old, the total volume increment was $1.430 \mathrm{~m}^{3}$. The second maximum increment in total tree volume was $1.424 \mathrm{~m}^{3}$ estimated at the age of 60 years while the second minimum increment in total tree volume was 0.037 at the age of 11 years old tree. The average age of the sample tree was 36.68 years with the increment in tree volume was $1.35 \pm 0.96 \mathrm{~m}^{3}$. Table 3 shows that the age of the sample tree increases with the increase in tree-volume increment which shows a positive correlation of tree age with basal area. The coefficient of variance and standard deviation are presented in Table 2 for tree age with increment in the total volume of sample trees. The sum of total increment in volume in all sample trees was $95.02 \mathrm{~m}^{2}$ which is presented in Table 4.
The minimum mean of annual tree-volume increment was $0.0039 \mathrm{~m}^{3}$ estimated at the age of 10 years old sample tree while the second minimum mean of annual total tree-volume was calculated at the age of 11 years old tree which was $0.021 \mathrm{~m}^{3}$. The maximum mean of annual total tree-volume was $0.069 \mathrm{~m}^{3}$ calculated at the age of 55 years, while the second maximum mean of annual total tree-volume increment was $0.062 \mathrm{~m}^{3}$ at the age of 60 years which is presented in Table 3. The tree age shows a correlation with mean annual increment in tree volume which is presented in Table 1 . The average means of annual tree-volume increment was $0.032 \pm 0.014 \mathrm{~m}^{3}$ at the age of 36 years, while the sum of the total mean of annual increment in tree volume of all sample trees was $2.264 \mathrm{~m}^{3}$ which are presented in Table 4 . The standard deviation and 
Table 3 Tree age correlation with total and mean annual tree volume/tree

\begin{tabular}{ccccccccc}
\hline $\begin{array}{c}\text { Age } \\
(\text { Years })\end{array}$ & $\begin{array}{c}\text { Tree } \\
\text { Vol. }\left(\mathrm{m}^{3}\right)\end{array}$ & $\begin{array}{c}\text { MA Tree } \\
\text { Vol. }\left(\mathrm{m}^{3}\right)\end{array}$ & $\begin{array}{c}\text { Age } \\
(\text { Years })\end{array}$ & $\begin{array}{c}\text { Tree } \\
\text { Vol. }\left(\mathrm{m}^{3}\right)\end{array}$ & $\begin{array}{c}\text { MA Tree } \\
\text { Vol. }\left(\mathrm{m}^{3}\right)\end{array}$ & $\begin{array}{c}\text { Age } \\
(\text { Years })\end{array}$ & $\begin{array}{c}\text { Tree } \\
\text { Vol. }\left(\mathrm{m}^{3}\right)\end{array}$ & $\begin{array}{c}\text { MA Tree Vol. } \\
\left(\mathrm{m}^{3}\right)\end{array}$ \\
\hline 10 & 0.010 & 0.004 & 35 & 0.116 & 0.024 & 45 & 0.499 & 0.034 \\
11 & 0.037 & 0.021 & 35 & 0.166 & 0.026 & 45 & 0.589 & 0.039 \\
12 & 0.058 & 0.017 & 36 & 0.209 & 0.027 & 45 & 0.609 & 0.039 \\
13 & 0.032 & 0.011 & 36 & 0.234 & 0.021 & 46 & 0.553 & 0.038 \\
15 & 0.045 & 0.011 & 36 & 0.261 & 0.025 & 46 & 0.420 & 0.040 \\
15 & 0.035 & 0.012 & 37 & 0.137 & 0.029 & 47 & 0.630 & 0.041 \\
15 & 0.066 & 0.015 & 37 & 0.155 & 0.030 & 47 & 0.622 & 0.042 \\
15 & 0.076 & 0.014 & 37 & 0.173 & 0.028 & 47 & 0.387 & 0.038 \\
16 & 0.046 & 0.017 & 37 & 0.076 & 0.023 & 47 & 0.585 & 0.037 \\
19 & 0.070 & 0.015 & 37 & 0.232 & 0.030 & 49 & 0.630 & 0.041 \\
20 & 0.096 & 0.017 & 37 & 0.300 & 0.034 & 49 & 0.739 & 0.044 \\
20 & 0.074 & 0.013 & 38 & 0.466 & 0.035 & 50 & 0.771 & 0.044 \\
20 & 0.115 & 0.022 & 39 & 0.361 & 0.036 & 50 & 0.922 & 0.045 \\
25 & 0.224 & 0.026 & 39 & 0.240 & 0.028 & 50 & 0.877 & 0.047 \\
28 & 0.147 & 0.030 & 40 & 0.266 & 0.033 & 51 & 0.664 & 0.050 \\
28 & 0.139 & 0.028 & 40 & 0.383 & 0.034 & 52 & 0.912 & 0.055 \\
29 & 0.061 & 0.007 & 42 & 0.484 & 0.034 & 53 & 1.120 & 0.059 \\
30 & 0.118 & 0.028 & 43 & 0.291 & 0.032 & 53 & 1.246 & 0.060 \\
30 & 0.164 & 0.029 & 43 & 0.351 & 0.035 & 53 & 1.059 & 0.065 \\
32 & 0.124 & 0.020 & 43 & 0.357 & 0.029 & 54 & 0.979 & 0.064 \\
32 & 0.193 & 0.027 & 43 & 0.283 & 0.034 & 55 & 1.324 & 0.065 \\
33 & 0.193 & 0.027 & 43 & 0.437 & 0.036 & 55 & 1.430 \\
33 & 0.126 & 0.017 & 44 & 0.585 & 0.037 & 60 & 1.424 & 0.069 \\
34 & 0.106 & 0.019 & & & & & 0.062 \\
\hline
\end{tabular}

Table 4 Descriptive statistics of tree age relation with total and mean annual tree volume

\begin{tabular}{llllclccc}
\hline \multicolumn{1}{c}{ Variable } & Unit & $\mathrm{N}$ & Min & Max & Mean & Sum & SD & CV (\%) \\
\hline Age & Years & 70 & 10 & 60 & 36.87 & 2581 & 12.75 & 34.59 \\
Tree volume & $\mathrm{m}^{3} /$ tree & 70 & 0.0100 & 1.420 & 1.350 & 95.020 & 0.960 & 71.15 \\
Mean annual tree volume & $\mathrm{m}^{3} /$ tree & 70 & 0.0039 & 0.068 & 0.032 & 2.264 & 0.014 & 45.76 \\
\hline
\end{tabular}

coefficient of variance of total and mean annual tree volume increment are presented in Table 4.

Figure 3 shows a strong positive correlation between tree age with total and mean annual treevolume increment. When the tree was 10 years old the total increment of tree volume was $0.010 \mathrm{~m}^{3}$ while at the age of 60 years the total increment in tree volume was $1.42 \mathrm{~m}^{3}$. This result showed a positive correlation meaning that when the age of the tree was increased the increment in tree volume was also occurred and the value of $R$ square was 0.9167 . The of $R$ square shows the strong positive correlation among tree age with tree-volume increment in sample trees which is presented in Figure 3 showing tree age relation with mean annual tree-volume increment. In another research results have several implications for efforts to apply age-dependent relationships to understand forest volume accumulation and fluxes were related to both stand age, implying that measures of forest age can be useful for understanding and assessing volume increment and fluxes in these forests. Despite several studies that illustrate agerelated patterns in forest volume increment (Bradford et al. 2008). Although this research resemble in terms of age of stand or history have impacts on total and mean annual volume accumulation. When the tree age was 10 years old the mean annual increment in tree volume was $0.0039 \mathrm{~m}^{3}$ which determine minimum tree volume while the maximum mean annual tree-volume increment was $0.068 \mathrm{~m}^{3}$ at age of 60 years. When the age of the tree increases with the increase in mean annual tree-volume increment from 10 to 60 years, it shows a strong positive correlation which is presented in Figure 4. The value of $R$ square was 0.8903 which showed a positive correlation between tree age with the increase in mean annual tree-volume increment when the tree age was increased with the increase in mean annual tree-volume increment (Figure 4). In the regression model to draw the correlation between tree age with tree-volume increment of sample trees, polynomial quadratic equation was used, while for the relationship between tree age with mean annual increment in tree volume in regression model, polynomial cubic equation was used for sample trees.

\section{CONCLUSIONS}

The study was conducted in the stand of Cedrus deodar which was grown at Kumrat valley Dir Upper KPK, Pakistan: tree age and increment based on increment core have been studied, the impacts of tree age on total and mean annual basal-area increment and annual tree-volume increment of the stand. Age is an independent variable and tree basal-area, and volume are dependent variables. The results reveal that the ages of sample trees increase with increment 


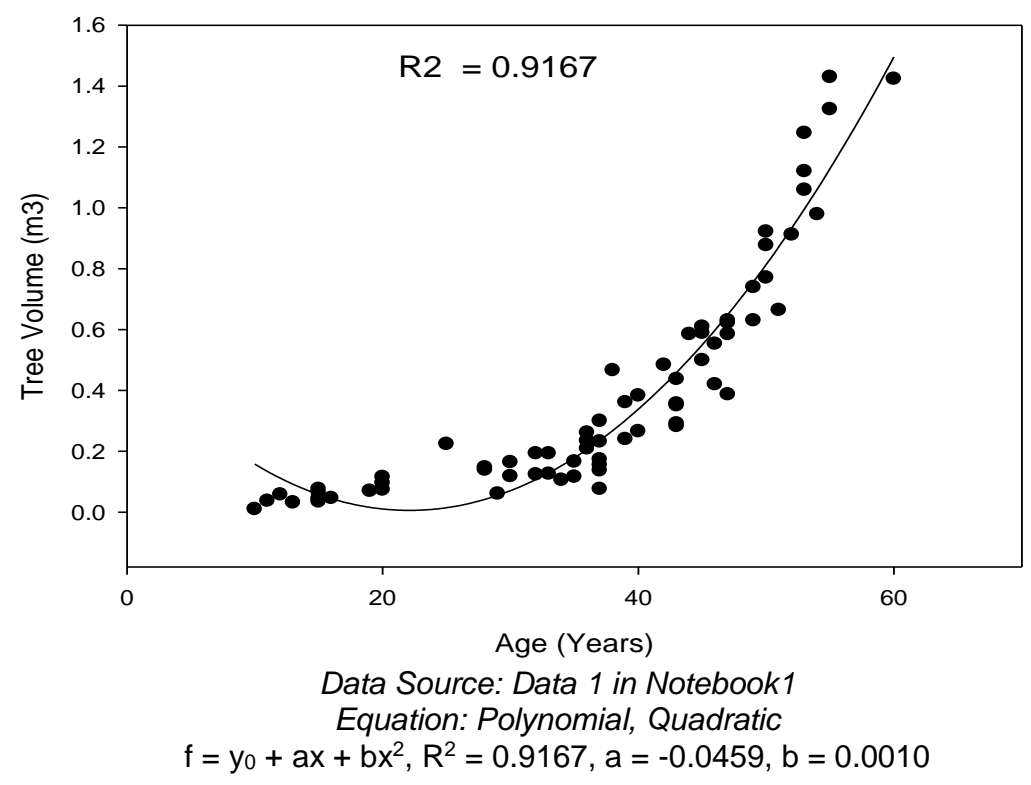

Figure 3 Tree age relation with total tree volume.

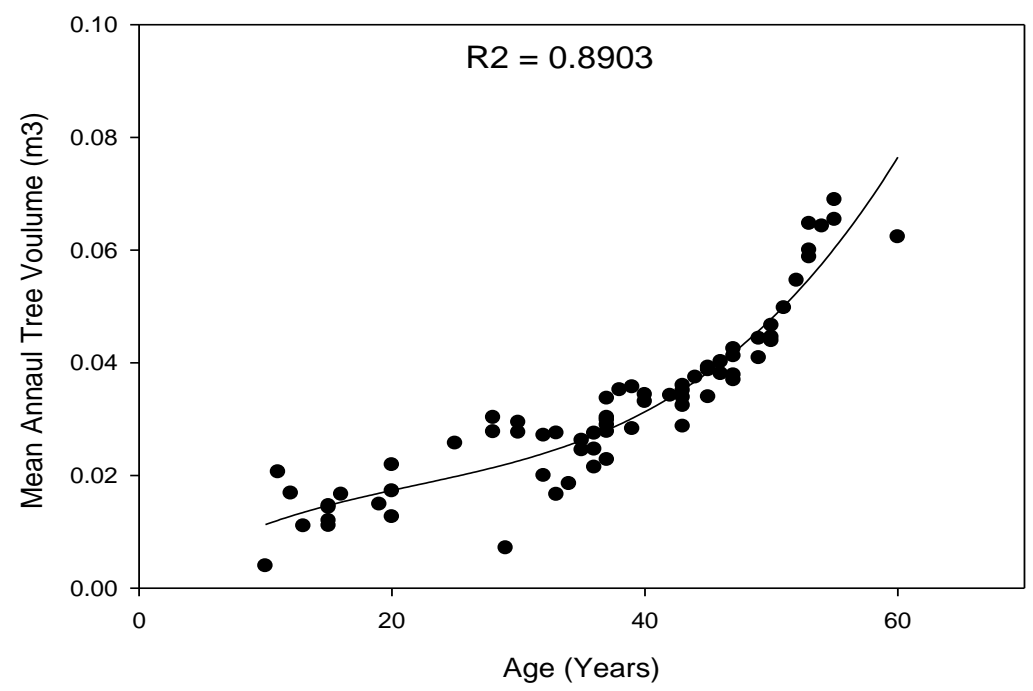

Data Source: Data 1 in Notebook1

Equation: Polynomial, Cubic

$f=y_{0}+a x+b x^{2}+c x^{3}, R^{2}=0.8903, y_{0}=5.0047, a=0.0015=0.0010, b=-4.7415, c=7.2044$

Figure 4 Tree age relation with mean annual tree volume.

in basal area and volume of trees. When tree age was 10 years old, the amount of increment calculated in tree parameters was lower compared to an age of 60 years old tree. It is concluded that the ages of trees in the stand have strong positive correlation with their increments in basal area and volume. Cedrus deodar is a light demander and slow growing species among coniferous trees in Pakistan which means it grows with slow growth rate and long rotation age. The increase of the plantation and seedling of conifers trees in northern areas of Pakistan, controls deforestation of conifers trees because it takes more time for its growth. Forestation and reforestation of conifers trees on degraded land and on steep slopes areas can be used to controls soil erosion. Increasing the forest areas with proper management that will give more economical, social, and biological benefits to a country like a forest that will provide habitat for wildlife, provide timber, fuel wood, watershed areas provide good quality of water, provides environmental services, and other NTFS. Conifers trees have a great potential for carbon sequestration to store carbon dioxide from the atmosphere.

\section{REFERENCES}

Arsalan, Siddiqui MF, Ahmed M, Shaukat SS, Hussain A. 2020. Population structure, age and growth rates of conifer species and their relation to 
environmental variables at Malam Jabba, Swat District, Pakistan. Journal of Forestry Research, 31(2): 429-441. https://doi.org/10.1007/s11676018-0820-5

Bhandari S. 2019. Dendroclimatic reconstruction in the Gilgit-Baltistan region of Pakistan using three Tree Genera. The College of Graduate and Professional Studies.

Bokhari TZ, Ahmed M, Khan ZUD, Siddiqui MF, Zafar MU, Malik SA. 2013. Dendroseismological potential of pine tree species of Azad Jammu and KashmirPakistan: A preliminary study. Pakistan Journal of Botany. 45(6): 1865-1871.

Bradford JB, Birdsey RA, Joyce LA, Ryan MG. 2008. Tree age, disturbance history, and carbon stocks and fluxes in subalpine Rocky Mountain forests. Global Change Biology. 14(12): 2882-2897. https://doi.org/10.1111/j.1365-2486.2008.01686.x

Fichtler E. 2017. Dendroclimatology using tropical broad-leaved tree species: a review. Erdkunde, 71(1): 5-22. http://www.jstor.org/stable/44280263

Heuret $P$, Caraglio $Y$, Sabatier SA, Barthélémy $D$, Nicolini EA. 2016. Retrospective analysis of plant architecture: an extended definition of dendrochronology. Tropical Ecology and Society Reconciliating Conservation and Sustainable Use of Biodiversity. Program and Abstracts.

ljaz F, Rahman IU, lqbal Z, Alam J, Ali N, Khan SM. 2018. Ethno-ecology of the Healing Forests of Sarban Hills, Abbottabad, Pakistan: An Economic and Medicinal Appraisal. In Plant and Human Health. 1(09): 675-706. Springer International Publishing. https://doi.org/10.1007/978-3-31993997-1_19

Iqbal J, Ahmed M, Siddiqui MF, Khan A. 2020. Tree Ring Studies From Some Conifers and Present Condition of Forests of Shangla District of Khyber Pakhtunkhwa, Pakistan. Pakistan Journal Botany. 52(2): 653-662. https://doi.org/10.30848/PJB20202(38)

lqbal J, Siddiqui MF, Khan A, Wahab M. 2017a. Age and radial growth analysis of conifer tree species from Shangla, Pakistan. Pakistan Journal of Botany, 49: 69-72. https://www.researchgate.net/ publication/317429320

Iqbal J, Siddiqui MF, Khan A, Wahab M. 2017b. Age and radial growth analysis of conifer tree species from Shangla, Pakistan Enthnobotany and Forest ecology View project Long-Term Drought Reconstruction and Dendroecology in moist temperate areas of Pakistan Using Tree-Rings View project. https://www.researchgate.net/ publication/317429320

Khan, Adam, Ahmed M, Siddiqui MF, Iqbal J, Narayan A, Gaire P. 2018. Dendrochronological potential oAbies Pindrow royle from Indus Kohistan, Khyber Pakhtunkhwa (KPK) Pakistan). In Pakistan Journal of Botany. 50(1).

Khan, Alamgir, Ahmad A, Rahman ZSD, Qureshi R, Muhammad J. 2015. The Assessment of Carbon Stocks in the Oak Scrub Forest of Sheringal Valley Dir Kohistan. Open Journal of Forestry. 5(5): 510517. https://doi.org/10.4236/ojf.2015.55044

Locosselli GM, Camargo EP, de Moreira TCL, Todesco $\mathrm{E}$, Andrade $\mathrm{M}$, de $\mathrm{F}$, André CDS, de André PA, de Singer JM, Ferreira LS, Saldiva PHN, Buckeridge MS. 2019. The role of air pollution and climate on the growth of urban trees. Science of the Total Environment. 666: 652-661. https://doi.org/ 10.1016/j.scitotenv.2019.02.291

Ols C, Girardin MP, Hofgaard A, Bergeron Y, Drobyshev I. 2018. Monitoring Climate Sensitivity Shifts in Tree-Rings of Eastern Boreal North America Using Model-Data Comparison: Shifts in Tree Growth Sensivity to Climate. Ecosystems, 21(5): 1042-1057. https://doi.org/10.1007/s10021017-0203-3

Peichl M, Arain MA. 2006. Above- and belowground ecosystem biomass and carbon pools in an agesequence of temperate pine plantation forests. Agricultural and Forest Meteorology. 140(1-4): 5163. https://doi.org/10.1016/j.agrformet.2006.08.004

Sajad ANJ. 2020. Evaluation of Biomass and Carbon Stocks by Inventory Method in Pure Pinus. 8(June), 371-377. http://ijmcr.com/evaluation-of-biomassand-carbon-stocks-by-inventory-method-in-purepinus-roxburghii-forest-in-matta-swat-khyberpakhtunkhwa-pakistan/

Sarangezaj OAAAM. 2017. Dendrochronological Approach To Estimate Age And Growih Rate Of Various Species From Himaiayan Region Of Pakistan. Pakistan Journal Botany. 23(1): 78-89.

Xing J, Li K, Hu W, Yuan C, Ling H. 2017. Diagnosing deep learning models for high accuracy age estimation from a single image. Pattern Recognition. 66: 106-116. https://doi.org/10.1016/j.patcog.2017.01.005

Zhao S, Pederson N, D'Orangeville L, HilleRisLambers J, Boose E, Penone C, Bauer B, Jiang Y, Manzanedo RD. 2019. The International Tree-Ring Data Bank (ITRDB) revisited: Data availability and global ecological representativity. Journal of Biogeography. 46(2): 355-368. https://doi.org/ 10.1111/jbi. 13488 